\title{
Revision of Bowmaniella sensu Băcescu, 1968 (Crustacea: Mysida: Mysidae: Gastrosaccinae): a taxonomic conundrum
}

\author{
RICHARD W. HEARD ${ }^{1} \&$ W. WAYNE PRICE ${ }^{2}$ \\ ${ }^{1}$ Department of Coastal Sciences, University of Southern Mississippi, Ocean Springs, Mississippi 39566-7000, \\ USA.E-mail: richard.heard@usm.edu \\ ${ }^{2}$ Department of Biology, University of Tampa, Tampa, Florida 33606, USA. E-mail: wprice@ut.edu
}

Table of contents

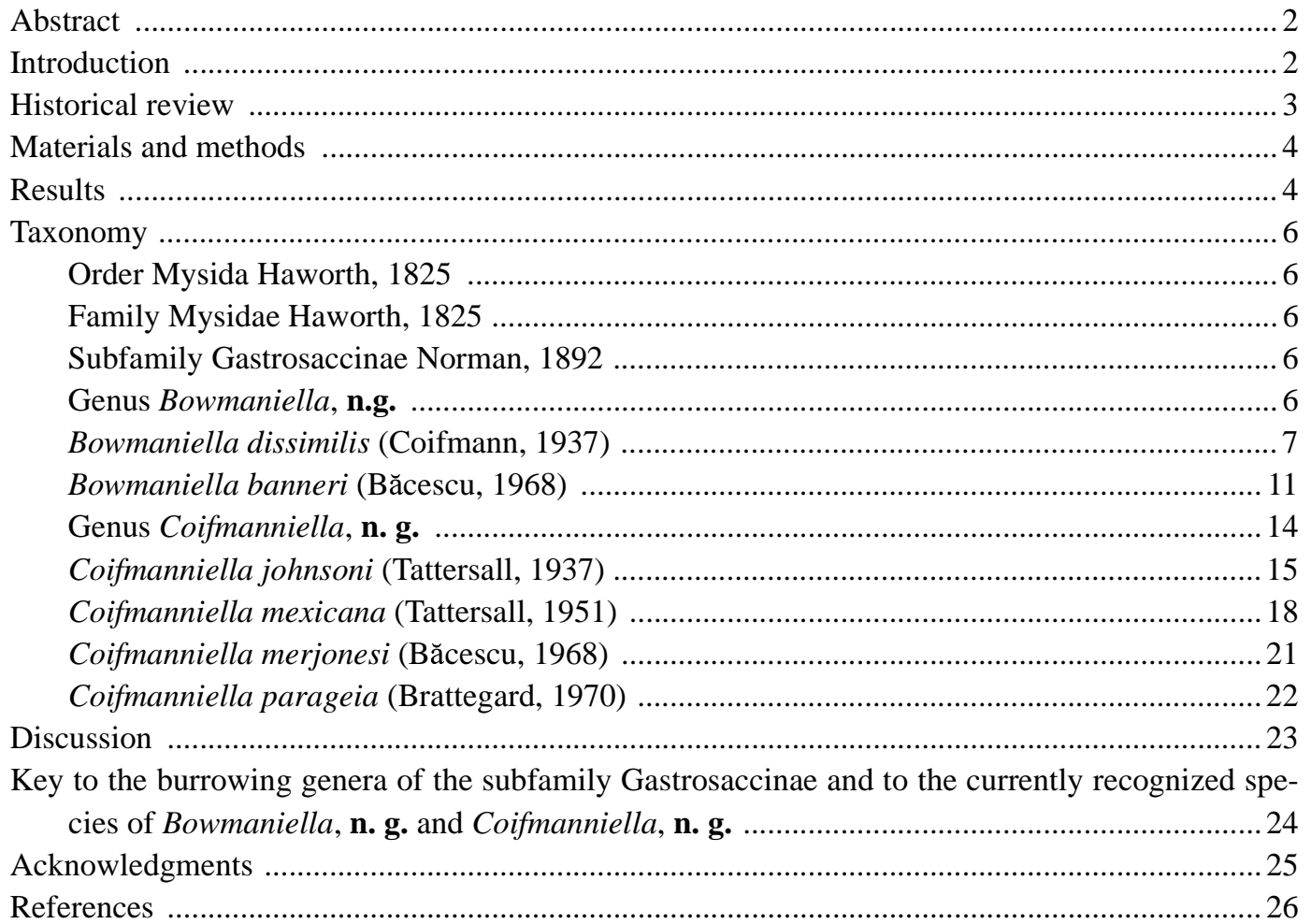




\section{Abstract}

There is confusion regarding the taxonomy, systematics, and distribution of species within the burrowing mysid genus Bowmaniella Băcescu, 1968. We have critically reviewed and examined the subgenera and the 15 nominal species currently assigned to Bowmaniella sensu Băcescu. Type material of eight of the 15 nominal species was examined and in vivo observations were made on two nominal species of the 'dissimilis group'. It was determined that in the ultimate (terminal form) and penultimate (subterminal form) males, the morphology of the third pleopods is distinctly different, a factor which has led to taxonomic confusion and the descriptions of several invalid species. Because Băcescu (1968) did not designate a type species for Bowmaniella or for the subgenus Coifmanniella, both taxa are nomina nuda. Our studies, especially those involving the development of the male third pleopod, also indicate that nine of the nominal species previously assigned to Bowmaniella Bacescu, 1968 are junior synonyms. We formally designate two new genera, Bowmaniella n. g. and Coifmanniella n. g., to accommodate the species previously listed under Bowmaniella and its subgenera as perceived by Băcescu (1968). We retain the use of Bacescu's original generic and subgeneric names, but with each having distinctly different diagnoses to those originally proposed by Băcescu. Bowmaniella $\mathbf{n}$. g. is diagnosed to receive $B$. dissimilis (type species) and B. banneri. Coifmanniella n. g. contains four species, $C$. johnsoni (type species), C. mexicana, C. merjonesi, and C. parageia. Lectotypes are designated for Bowmaniella dissimilis, B. banneri, Coifmanniella mexicana and C. merjonesi and a neotype is designated for $C$. johnsoni. Illustrated keys are given for the seven "burrowing" genera presently assigned to the Gastrosaccinae and for the species currently assigned to the American genera Bowmaniella and Coifmanniella.

Key words: Mysida, Mysidae, Gastrosaccinae, Bowmaniella, Coifmanniella, revision, new genera, taxonomy

\section{Introduction}

Over the past 25 years, we have collected and examined numerous specimens of Bowmaniella Băcescu, 1968 representing 11 of 15 nominal species. The members of the genus Bowmaniella are burrowing species of moderate size (8-12 $\mathrm{mm}$ TL) with a distribution limited to the Atlantic and Pacific coasts of the Americas. Our observations are based on material from the Bahamas, Brazil, Caribbean, Gulf of Mexico, US eastern seaboard, and from the eastern Pacific coasts of California and Costa Rica. We also conducted in vivo studies on specimens within the 'dissimilis group' that were designed to determine what effect the development of male third pleopod might have on the taxonomy and systematics of the genus Bowmaniella sensu Băcescu (1968). The following taxonomic and systematic revision of the genus Bowmaniella is a result of these observations and our critical review of the literature. 
Norman (1892) erected the subfamily Gastrosaccinae to accommodate the genera Gastrosaccus Norman,1868 and Anchialus Sars, 1876 (=Anchialina Norman \& Scott, 1906). Băcescu (1968) split the genus Gastrosaccus into three genera: Gastrosaccus, known from the warm waters of the western Pacific, Indian Ocean, Mediterranean, and eastern Atlantic (Băcescu 1968); Iiella Băcescu, 1968, confined to the tropical and temperate western Pacific (Takahashi \& Kawaguchi 1997, Jo et al. 1998, Băcescu 1968), and Bowmaniella Băcescu, 1968, restricted to the temperate and tropical waters of the Americas. Băcescu (1968) transferred three nominal species of Gastrosaccus (G. dissimilis Coifmann, 1937; G. johnsoni Tattersall, 1937; G. mexicanus Tattersall, 1951) previously described from American waters to the new genus Bowmaniella and described three additional new western Atlantic species (B. brasiliensis, $B$. merjonesi and $B$. portoricensis). He further proposed a new species, B. banneri, based on the description and illustrations for Archaeomysis maculata of Tattersall $(1932,1951)$ [not Archaeomysis (=Callomysis) maculata (Holmes, 1894)], from the eastern Pacific waters of southern California (La Jolla), but failed to designate a type. Although Băcescu (1968) assigned a type species for Iiella, he did not designate one for Bowmaniella. He further divided Bowmaniella into the subgenera Bowmaniella and Coifmanniella, but again did not designate a type species for either taxon. When describing B. bacescui, B. parageia and $B$. sewelli from Bahamian waters, Brattegard (1970a) did not recognize Băcescu's two subgenera because of overlapping characters and other morphological inconsistencies. Brattegard divided Bowmaniella into three assemblages, the dissimilis, mexicana, and johnsoni 'groups', based primarily on the shape of the posterodorsal margin of the carapace (reflected or non-reflected), the morphology of third male pleopod, and the presence or absence of an articulate process on the posterodorsal margin of the fifth abdominal segment (see Fig. 1). During the 1970s Silva described three species, $B$. atlantica Silva, 1971 (=Gastrosaccus brasiliensis sensu Silva 1970), B. recifensis Silva, 1971, and B. inarticulata Silva, 1972. Holmquist (1975), based on Brattegard's (1970a) supplemental description and illustrations of $C$. dissimilis from southern Florida, designated this North American material as a new species, B. floridana. In the same report she redescribed B. banneri and, since Băcescu (1968) had failed to do so, designated an adult male from her Baja California material as a neotype for the species. Later, Holmquist (1982) indicated that she had erred in the designation for the neotype of B. banneri. She acknowledged that the type should have been chosen from the La Jolla specimens that Tattersall $(1932,1951)$ originally attributed to Archaeomysis maculata, and upon which Băcescu (1968) based his specific designation for C. banneri. The last member of the genus to be described, B. gutzui Ortiz, 1988, came from Cuban waters, bringing the total number of nominal species for the genus to 15 . 
Specimens were collected in the Gulf of Mexico (Marco Island, Florida to Laguna Madre, Texas), the southeastern U.S. Atlantic coast (North Carolina to eastern Florida), Turks and Caicos Islands (Pine Cay), the Caribbean (Cayman Islands, Tobago, Costa Rica) and the Pacific coast of Costa Rica and are in the personal collections of the authors maintained in the Department of Coastal Sciences, University of Southern Mississippi (USM) or the Department of Biology, University of Tampa (UT). Type material and additional western Atlantic material from the collections of the National Museum of Natural History (USNM), American Museum of Natural History (AMNH), Muséum d'Histoire naturelle "Grigore Antipa", The Natural History Museum (NHM), Britain, Museo Zoologico de "La Specola," Italy (MZS) and Museu Nacional (MNB), Brazil were also examined during our investigation. Other abbreviations used include: ICZN for International Code of Zoological Nomenclature, TL for total length (i.e., tip of rostrum to tip of telson)

Living specimens of male Bowmaniella (Coifmanniella) brasiliensis sensu Băcescu (1968), a suspected penultimate stage within the 'dissimilis group', were collected from Tampa Bay, Florida (FL) and Mississippi Sound (Horn Island), Mississippi (MS). Individual specimens were maintained at room temperature in small plastic containers or finger bowls containing seawater (20-32\%o). Specimens were observed several times daily, until either moulting or death occurred. Water in the bowls was changed daily and newly hatched (less than six hours post hatching) Artemia sp. nauplii were added as a food source. After a successful or partial moult occurred, both the newly moulted specimen and its unattached (or still partially attached exuvia) were examined immediately with a compound microscope and preserved for further examination.

\section{Results}

Our studies revealed that species assigned to Bowmaniella sensu Băcescu (1968) have two morphologically distinct developmental stages of the male third pleopods. Referred to here as the penultimate (subterminal) and ultimate (terminal) forms, the former is structurally less complex than the latter (see Tables 1, 2; Fig. 2). The previously unreported existence of two distinct male forms has led to the erroneous designation of several invalid species. Respectively, Table 2 and Figure 2 list and illustrate some of the morphological characters that distinguish these two pleopod types. Based on our observations and examination of type material, we now consider that 9 of the 15 nominal species formally attributable to Bowmaniella sensu Băcescu (1968) are junior synonyms.

As pointed out by Brattegard (1971), there are inconsistencies with characters used by Băcescu (1968) in establishing the subgeneric designations, which made it impractical to use, especially now in light of the recognition of penultimate and ultimate forms of the males. As originally proposed by Băcescu (1968), the subgenus Bowmaniella contained 
two species, $B$. (B.) johnsoni and $B(B$.) portoricensis Băcescu, 1968, and the subgenus Coifmanniella contained B. (C.) banneri; B.(C.)brasiliensis, B. (C.) dissimilis, B. (C.) merjonesi and $B$. $(C$.) mexicana. In our revision we use the presence or absence of the articulated dorsal process on the fifth abdominal segment, the setation of the surface of the uropodal endopod, and the morphology of the male ultimate and penultimate third pleopod as the key generic characters to distinguish the two new genera.

TABLE 1. Species of Bowmaniella n. g. and Coifmanniella n. g. with synonyms, male stage originally described, and configuration of medial lobes of posterodorsal margin of carapace as indicated or depicted by earlier authors.

\begin{tabular}{|c|c|c|}
\hline Species & $\begin{array}{l}\text { Original male stage } \\
\text { Described }\end{array}$ & $\begin{array}{l}\text { Medial Lobes of } \\
\text { Carapace }\end{array}$ \\
\hline \multicolumn{3}{|l|}{ Bowmaniella Băcescu, 1968, n.g } \\
\hline $\begin{array}{l}\text { Bowmaniella dissimilis (Coifmann, 1937), type sp. } \\
\text { Synonyms: }\end{array}$ & Penultimate & non-reflected \\
\hline Bowmaniella floridana (Holmquist, 1975) & Ultimate & non-reflected \\
\hline Bowmaniella brasiliensis (Băcescu, 1968) & Penultimate & non-reflected \\
\hline Bowmaniella banneri (Băcescu, 1968) & Ultimate & non-reflected \\
\hline \multicolumn{3}{|l|}{ Coifmanniela Băcescu, 1968, n.g } \\
\hline $\begin{array}{l}\text { Coifmanniella johnsoni (Tattersall, 1937), type sp. } \\
\text { Synonym: }\end{array}$ & Ultimate & non-reflected \\
\hline Bowmaniella bacescui Brattegard, 1970 & Ultimate & non-reflected \\
\hline Coifmanniella merjonesi (Băcescu, 1968) & Penultimate & reflected \\
\hline \multicolumn{3}{|l|}{ Synonyms: } \\
\hline Bowmaniella inarticulata Silva, 1971 & Penultimate & reflected \\
\hline Bowmaniella recifensis Silva, 1975 & Ultimate & reflected \\
\hline Coifmanniella mexicana (Tattersall, 1951) & Penultimate & reflected \\
\hline \multicolumn{3}{|l|}{ Synonyms: } \\
\hline Bowmaniella atlantica Silva, 1971 & Ultimate & reflected \\
\hline Bowmaniella gutzui Ortiz, 1988 & Ultimate & reflected \\
\hline Bowmaniella portoricensis Băcescu, 1968 & Ultimate & reflected \\
\hline Coifmanniella parageia (Brattegard, 1970) & Ultimate & reflected \\
\hline \multicolumn{3}{|l|}{ Synonym: } \\
\hline Bowmaneilla sewelli Brattegard, 1970 & Penultimate & reflected \\
\hline
\end{tabular}

Based on Articles 66 and 69 of the1999 Fourth Edition of the International Code of Zoological Nomenclature (ICZN), we initially considered the possibility of emending the 
diagnoses for Bacescu's Bowmaniella and Coifmanniella with the elevation of the later to full generic rank. Because no type species were designated for Bowmaniella sensu Băcescu (1968) and its two subgenera B. (Bowmaniella) and B. (Coifmanniella), which were introduced informally in a dichotomous key to the species (Băcescu, 1968), we now choose to follow Article 13 of the ICZN and consider them nomina nuda This situation makes it necessary to designate two new genera to accommodate the species previously assigned to Bowmaniella sensu Băcescu, 1968. We chose to retain the use of B?cescu's original generic and subgeneric names, Bowmaniella and Coifmanniella, but with each having distinctly different diagnoses than those originally proposed.

TABLE 2. Terminology of structures for distal complex of male third pleopod for penultimate and ultimate forms of Bowmaniella n. g. and Coifmanniella n. g. Terminology follows Brattegard (1970a). (+ = presence, $-=$ absence).

\begin{tabular}{lll}
\hline Structure & Penultimate Form & Ultimate Form \\
\hline Bow & - & + or - \\
apophysis & - & + or - \\
Inner branch & + & + \\
inner stylet & + or - & + \\
accessory lobe & + & + \\
distal lobe & + (not striated $)$ & + (striated $)$ \\
apophysis & + & - \\
Outer Branch & + & + \\
outer stylet & - & + \\
blade & + & + \\
apical spine & + & + \\
sub-apical spine & + & + \\
ventral process & + or - & - \\
\hline
\end{tabular}

\section{Taxonomy}

Order Mysida Haworth, 1825

Family Mysidae Haworth, 1825

Subfamily Gastrosaccinae Norman, 1892

\section{Genus Bowmaniella, n.g}

Archaeomysis.-Tattersall, 1932, 1951: 86 (in part, not Archaeomysis Czerniavsky, 1882). 
Gastrosaccus.-Tattersall, 1951: 89 (in part, not Gastrosaccus Norman, 1868).

Bowmaniella Băcescu, 1968: 356. (nomen nudum).

Bowmaniella (Coifmanniella) Băcescu, 1968: 356 (in part) (nomen nudum).

Diagnosis. Carapace with posterodorsal margin having mid-dorsal lobe convex and adjacent medial lobes quadrate not attenuated or reflected anteriorly (Fig. 8 F). Abdominal segment 5 with articulated process present on posterodorsal margin. Third male pleopod highly modified; terminal male without bow (Figs. 2D), or if bow present (Fig. 6D, E), lacking apophysis; penultimate male lacking ventral process on outer branch, inner stylet present on inner branch (Figs. 2C, 6C). Uropodal endopod lacking small spiniform-setae immediately distal to statocyst (Fig. 5A, B). Telson cleft shallow, less than $15 \%$ of telson length (Fig. 4A, B).

Type species. Gastrosaccus dissimilis Coifmann, 1937, here designated.

Other species. Bowmaniella banneri (Băcescu, 1968).

Etymology. The genus was named in honour of the late Thomas Bowman, Senior Curator of the Division of Crustacea, National Museum of Natural History, The Smithsonian Institution.

Remarks. As now defined Bowmaniella n. g. contains two species, the type B. dissimilis (Coifmann, 1937) from the western Atlantic, and its eastern Pacific cognate, B. banneri (Băcescu, 1968). Bowmaniella is characterized by: (1) an articulated, posterodorsal process on the fifth abdominal segment (see Fig. 1); (2) the ultimate or terminal male form with third pleopod lacking a bow, or if bow present, lacking apophysis; (3) the penultimate male form with third pleopod lacking ventral process on outer branch and having an inner stylet present on inner branch; (4) lacking small spiniform-setae posterior to the uropodal statocyst; and (5) the posterodorsal margin of carapace having mid-dorsal lobe convex with adjacent medial lobes quadrate, not attenuated or reflected anteriorly. Based on examination of type material and the literature, two of the four nominal species attributable to Bowmaniella n. g. are synonyms. The status of these synonymies is discussed in the remarks section for the type species.

\section{Bowmaniella dissimilis (Coifmann, 1937)}

(Figs. 1, 2C-D, 4A, 5A, 6A-B, 8F)

Gastrosaccus dissimilis Coifmann, 1937: 5, figs. 2-3; Tattersall, 1951: 97, fig. 29; Costa, 1964: 4, pl. 1, figs. 1-4; Hopkins, 1965: 88; 1966: 29 (table); Odum \& Heald, 1972: 682; Christmas \& Langley, 1973: 274, 308.

Bowmaniella(Coifmanniella) dissimilis.-Băcescu, 1968: 357 (key), 363, fig. 4; Brattegard, 1970a: 
9,11, fig. 2; Williams, 1972: 255; Dexter, 1974: 57 (table); Livingston et al., 1977: 83; Cooley, 1978: 25.

Bowmaniella cf. dissimilis.-Brattegard, 1974a: 51.

Bowmaniella (Coifmanniella) brasiliensis Băcescu, 1968: 357 (key), 363, figs. 5a-d, 6; Conte \& Parker, 1971: 73; Almeida Prado, 1973: 409; Brattegard, 1974b: 91; Price, 1978: 173; Stuck et al., 1979a: 226 (key), 2d, 3d, 4c, 5d, 7; 1979b: 244; Price, 1982: 13, fig. 4; Heard, 1982: 32; Modlin, 1982: 46 (new synonymy).

Bowmaniella floridana Holmquist, 1975: 68; Stuck et al., 1979a: 227, fig. 2c, 3c, 4d, 5c, 6; Stuck et al., 1979b: 244; Heard, 1982: 32; Modlin, 1982: 46; Price, 1982: 14, figs. 2, 3; Escobar-Briones \& Soto, 1988: 640; Rakocinski et al., 1991: 693(table); Rakocinski et al., 1993: 88 (figure), 1996: 339 (new synonymy).

\section{Material examined}

Type material: Lectotype, $10^{*}$, MZS 2740, off Brazil, $15^{\circ} \mathrm{S}, 38^{\circ} \mathrm{W}, 31$ July 1882. Paralectotypes:, 3 ㅇ, $1 \sigma^{\pi}, 2$ juveniles, MZS 2741, same data as lectotype.

Other material: North America.—3 o $\sigma^{\star}$ UT, Savannah Beach, Georgia, 20 July 1974, coll. J. Ogle, beam trawl.-10 ơ 10 ㅇ, UT, Little Tybee, Savannah, Georgia 10 June 1991, coll. R. Heard and D. Roccatagliata, sandy beach, swash zone.-1 ơ $^{\star} 3$ 우, UT, Cape Coral Bridge, Caloosahatchee River, Florida, 11 July 1982, coll. W. Price, sand, depth $1 \mathrm{~m}$.-6 ${ }^{x}, 15$ ㅇ, UT, Picnic Island, Tampa Bay, Florida, 26 Sept 1976, coll. W. Price, sand, depth 1 m.-8 ơ, Davis Bayou, Mississippi, mud.-12 $\sigma^{\pi}$, USM, Belle Fontaine Beach, Mississippi, silty sand.—2 ơ USM, Dauphin Island, Alabama.-1 $\sigma^{\star}$, USNM 82434, beach near Calcasieu Pass, Louisiana, sta. 18, 18 Nov 1906, coll. W. H. Spaulding. $-5 \sigma^{\star}$, 19 ㅇ, UT, BB-3-TL, Baffin Bay, Texas, 2 Dec 1970, otter trawl.-2 ox, 1 ㅇ, UT, Six Mile Road, Galveston Island, Dec 1971, coll. W. Price, sand, depth 1 m. -4 ㅇ, UT, Galveston Island, east end, Dec 1971, coll. W. Price, sand beach depth 1 m.-7 $\sigma^{x}, 10$ 우, UT, Tuxpan, Veracruz, Mexico, $21^{\circ} 00^{\prime} \mathrm{N}, 97^{\circ} 21^{\prime} \mathrm{W}, 24$ May 1973, coll. W. Price, sand beach, depth $1 \mathrm{~m}$. Central America._-1 ơ, 10 우, UT, Montzanillo, Costa Rica, 17 Nov 1999, coll. R. Heard, sand beach, depth 1 m.-7 $\sigma^{x}, 10$ ㅇ, UT, sta 1, Puerto Vargas, Costa Rica, 18 Nov 1999, coll. R. Heard. South America 10 ơ, 17 ㅇ, UT, sta 4, Bloody Bay, Tobago, 4 Apr 1992, coll. R. Heard.-2 ox, 3 ㅇ, MNB 9734, Lage de Santos, Brazil, 18 May 1961, coll. Plinio Soares, MNC.

Diagnosis. Abdominal somite 5 with articulated posterodorsal process (Fig.1). Exopod of male pleopod 3 of ultimate form lacking bow, inner branch with inner stylet short and robust, reaching less than one-half length of distal article (Fig. 2 D; Fig. 6 B). Uropodal endopod lacking small spiniform setae distal to statocyst (Fig. 5A).

Type locality. Coast of Brazil $\left(15^{\circ} \mathrm{S}, 38^{\circ} \mathrm{W}\right)$.

Distribution. Western Atlantic: temperate, subtropical and tropical shallow coastal waters along the mainland or near shore islands from Delaware Bay, USA, southward to just south of Rio de Janeiro, Brazil (Brattegard 1970a). 


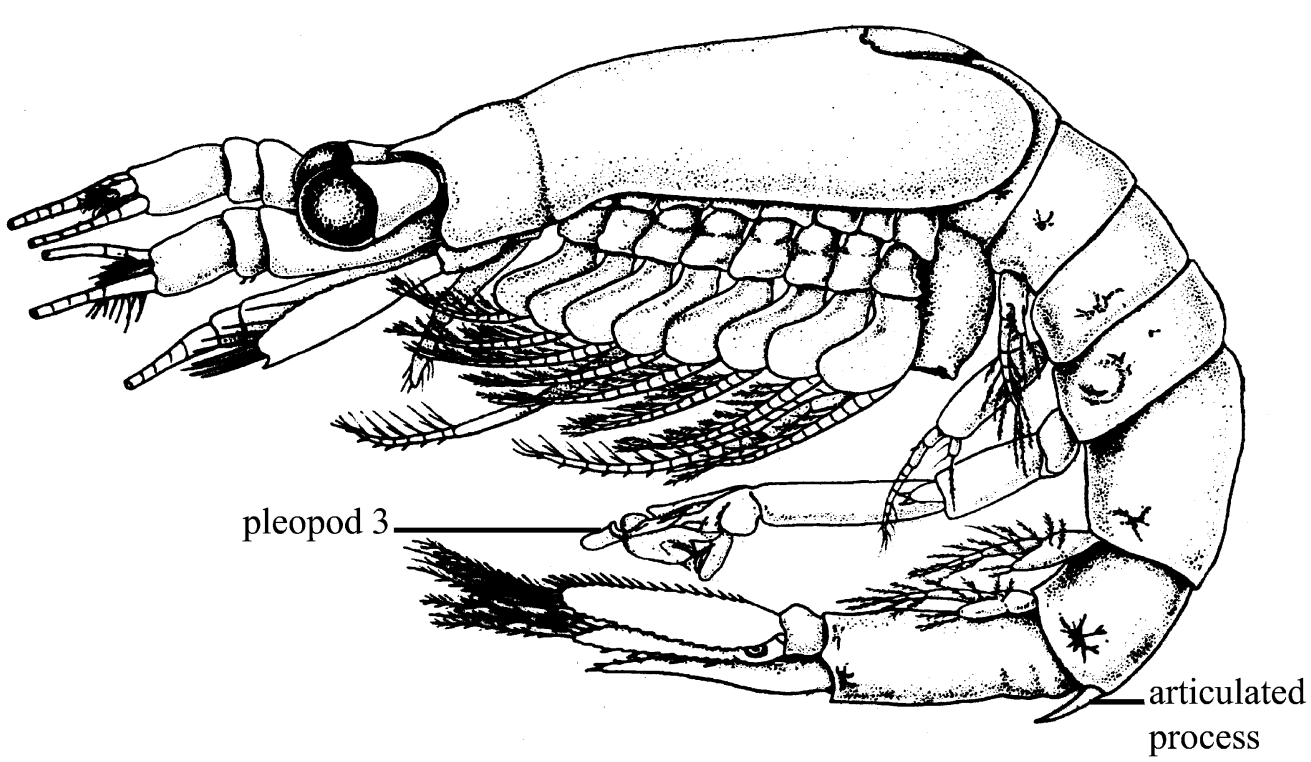

FIGURE 1. Bowmaniella dissimilis (Coifmann, 1937), lateral view of the penultimate male (from Băcescu 1968).

Remarks. Bowmaniella dissimilis was originally described from Brazilian waters by Coifmann (1937) as Gastrosaccus dissimilis. Although not entirely accurate, her drawing of the third male pleopod appears to represent the penultimate male form. Through the kindness of Dr. Gianna Innocenti of the Museo Zoologico de "La Specola", Florence, Italy, we were able to examine Coifmann's type material for which no holotype was designated. The lot that we examined contained seven specimens, one adult male (with one of the third pleopods removed), one subadult male, three females, and two desiccated juveniles. The latter two badly damaged specimens apparently were not included in Coifmann's five syntypes, and they agree in both sex and stage of development with those we examined. Because the adult male appears to be the specimen upon which Coifmann based her description, we have chosen it as the lectotype (MZS Cat. No. 2740) for $B$. dissimilis, and have separated the specimens from Coifmann's four remaining paralectotypes (i.e. MZS Cat. No. MZS 2741).

Tattersall (1951) considered that another Brazilian mysid Chlamydopleon aculeatum Ortman, 1893, belonged to the genus Gastrosaccus and believed that it was conspecific with G. dissimilis; however, because the description and illustration of $C$. aculeatum were so incomplete and its type apparently lost, he did not choose to formally synonymize the two species.

The taxonomic status of Bowmaniella dissimilis has been a problem for years, since Coifmann's (1937) original description and illustrations are not clear. Her drawing of the third male pleopod appears to be based on a penultimate male; the illustration is too incomplete for accurate comparison to Bowmaniella floridana sensu Holmquist (1975), 
Stuck et al. (1979a), or Price (1982). In his supplemental description of Florida specimens identified as B. dissimilis, Brattegard (1970a) stated that the inner stylet on the third pleopod of the terminal male stage was absent. Holmquist (1975), based in part on the apparent absence of a 'bow' ( sensu Stuck et al. 1979a \& Price 1982; = inner stylet sensu Brattegard 1970a) designated a new species, B. floridana. Stuck et al. (1979b) and Price (1982) examined specimens of $B$. dissimilis from the southeastern United States, including southern Florida, and all of the terminal males examined had inner stylets on the third pleopods. Brattegard (personal communication, 1979) reexamined his Florida specimens of B. dissimilis and observed the presence of the inner stylet sensu Holmquist (1975) thus confirming the invalidation of $B$. floridana.

Prior to 1975 most records for the genus Bowmaniella from estuarine and beach habitats along the southeastern United States were referred to $B$. dissimilis. Bowmaniella brasiliensis and $B$. floridana were reported to co-occur in the shallow coastal waters of the Gulf of Mexico by Stuck et al. (1979a, b) and Price (1982). These authors illustrated the distinctively modified copulatory structures on the third pleopods of the males of both species (see Fig. 2C, D), but they were unable to reliably differentiate the females and subadult males of these two species. Notwithstanding the differences in the third pleopods, the morphology, pigmentation pattern, and microhabitat for $B$. brasiliensis and $B$. floridana are the same in the populations they examined from the northern Gulf of Mexico.

Based on these factors, we postulated that the third male pleopod of Bowmaniella. floridana, the larger and more complex of the two species, represents the ultimate or terminal stage of development and that the male of $B$. brasiliensis is the penultimate or subterminal stage of the same species.

To test this hypothesis, we isolated single living males of Bowmaniella brasiliensis collected from shallow-water habitats at Horn Island, MS and Tampa Bay, FL in small bowls containing sea water. When these specimens moulted, the newly moulted specimen and its exuvia were examined. Based on 15 different observations, all of the 'brasiliensis' male forms moulted into the 'floridana' male form confirming the synonymy of the two species.

We have examined large numbers Bowmaniella dissimilis from North Atlantic waters, including a terminal male form, from near the type locality in the State of Rio de Janeiro, Brazil. We have also studied an excellent series of specimens attributable to $B$. dissimilis from Tobago, off the northeastern coast of South America. As a result of these studies and Brattegard's reexamination of his Florida specimens (Brattegard, personal communication 1979), we now consider that $B$. brasiliensis and $B$ floridana are junior synonyms of $B$. dissimilis. Notwithstanding, we currently consider $B$. dissimilis to be the only species of the genus in the northwestern Atlantic. It is known from the shallow waters of the east coasts of the Americas from Delaware, USA to southern Brazil. We did notice that the individuals from some populations (e.g. southeastern Costa Rica) were distinctively larger 
than those from other regions, but we tentatively consider these differences ecophenotypic or a sampling artifact (e.g. time of year collected). There still remains, however, the possibility of morphologically similar cryptic species occurring within the broad range attributed to $B$. dissimilis. Comparative DNA studies on northern and southern, or isolated populations (e.g. Tobago) of $B$. dissimilis would be needed to refute or support this possibility.

\section{Bowmaniella banneri (Băcescu, 1968)}

(Figs. 4B, 5B, 6C-E)

Archaeomysis maculata Tattersall, 1932: 304, figs.1-13; 1951: 86, figs. 23-24 [not Archaeomysis (=Callomysis) maculata (Holmes, 1894)].

Archaeomysis sp. Banner, 1948: 370; Ii, 1964: 220.

Bowmaniella (Coifmanniella) banneri Băcescu, 1968: 356 (key); Holmquist, 1975: 63, figs. 6-8, 1982: 477, fig. 3.

Bowmaniella sp A, B, C, Dexter, 1974: 59 (table).

Material examined. $4 \sigma^{\star}, 5$ ㅇ, USNM 98173, San Felipe, Baja California, Mexico, 24 Feb 1955, coll. R. H. Linsley, low tide.-1 ○`, 4 우 UT, Caldera, Bahia de Caldera, Costa Rica, 28 April 1998, coll. R. W. Heard and R. Vargas beach, depth 1-1.5 m.—2 우, UT, Islas de Murcielago NE end of San Jose Island (just east of shallow pass between Catalina and San Jose Islands), Costa Rica, 8 May 1999, coll. R. W. Heard, Jorge Cortes and Rita Vargus, sand substratum, depth 6-7 m.-3 $\circ^{x}, 5$ ㅇ, USNM uncatalogued, acc. no. 295277, Boca de Barranca, Puentarenas, Costa Rica, $9^{\circ} 58^{\prime} \mathrm{N}, 84^{\circ} 45^{\prime} \mathrm{W}$, coll. D. Dexter, volcanic sand substratum. 6 o 6 , 6 9, USNM uncatalogued (acc. no. 295277), Jáco, Playa de Jáco, Costa Rica, 9³7'N, 84³8' W, 27 Mar 1971, coll. D. Dexter, volcanic sand substratum.—8 우, USNM uncatalogued (acc. no. 295277), Playa Cocal, Quepos, Costa Rica, 9²6'N, $84^{\circ} 10^{\prime} \mathrm{W}, 27 \mathrm{Feb} 1971$, volcanic sand substratum.

Diagnosis. Abdominal somite 5 with articulated posterodorsal process (as in Fig. 1). Exopod of male pleopod 3 of ultimate form with bow, inner branch with inner stylet fairly slender, reaching more than one-half length of distal article (Fig. 6D, E) Uropodal endopod lacking small spiniform setae distal to statocyst (Fig. 5B).

Type locality. La Jolla, California.

Distribution. Eastern Pacific Ocean, temperate, subtropical and tropical shallow coastal waters along the mainland from Solana Beach, California (Holmquist 1982), to near Quepos, Costa Rica $\left(9^{\circ} 26^{\prime} \mathrm{N}, 84^{\circ} 10^{\prime} \mathrm{W}\right)$ (Dexter 1974). 

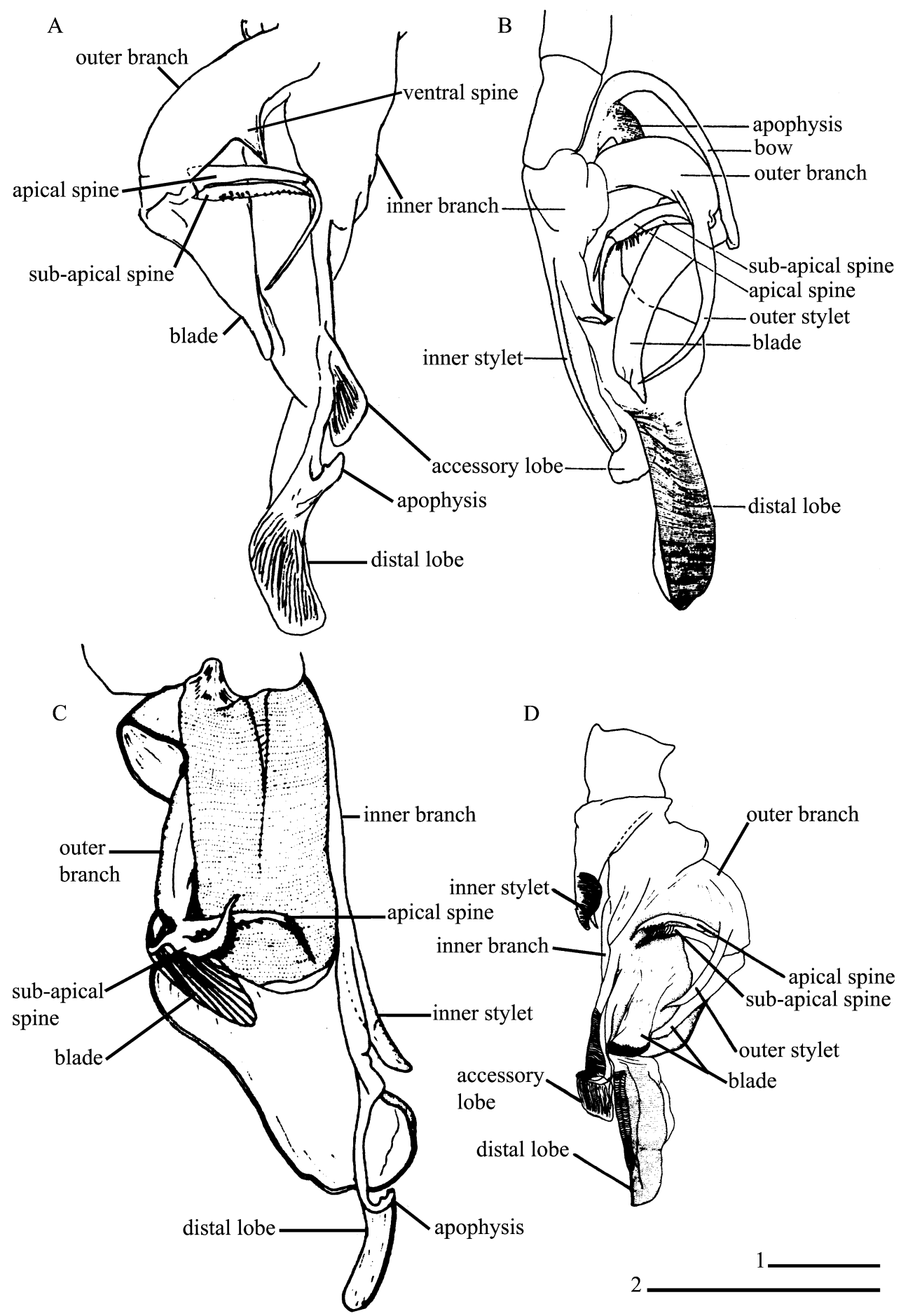

FIGURE 2. Tip of male pleopod 3. Coifmanniella johnsoni (Tattersall, 1937): A, penultimate form; B, ultimate form (from Brattegard 1970a). Bowmaniella dissimilis (Coifmann, 1937): C, penultimate form (from Stuck et al. 1979a); D, ultimate form (from Stuck et al. 1979a). Scale 1 = $0.1 \mathrm{~mm}$ for $\mathrm{A}$; scale $2=0.5 \mathrm{~mm}$ for $\mathrm{D}, 1.0 \mathrm{~mm}$ for $\mathrm{B}, \mathrm{C}$. 

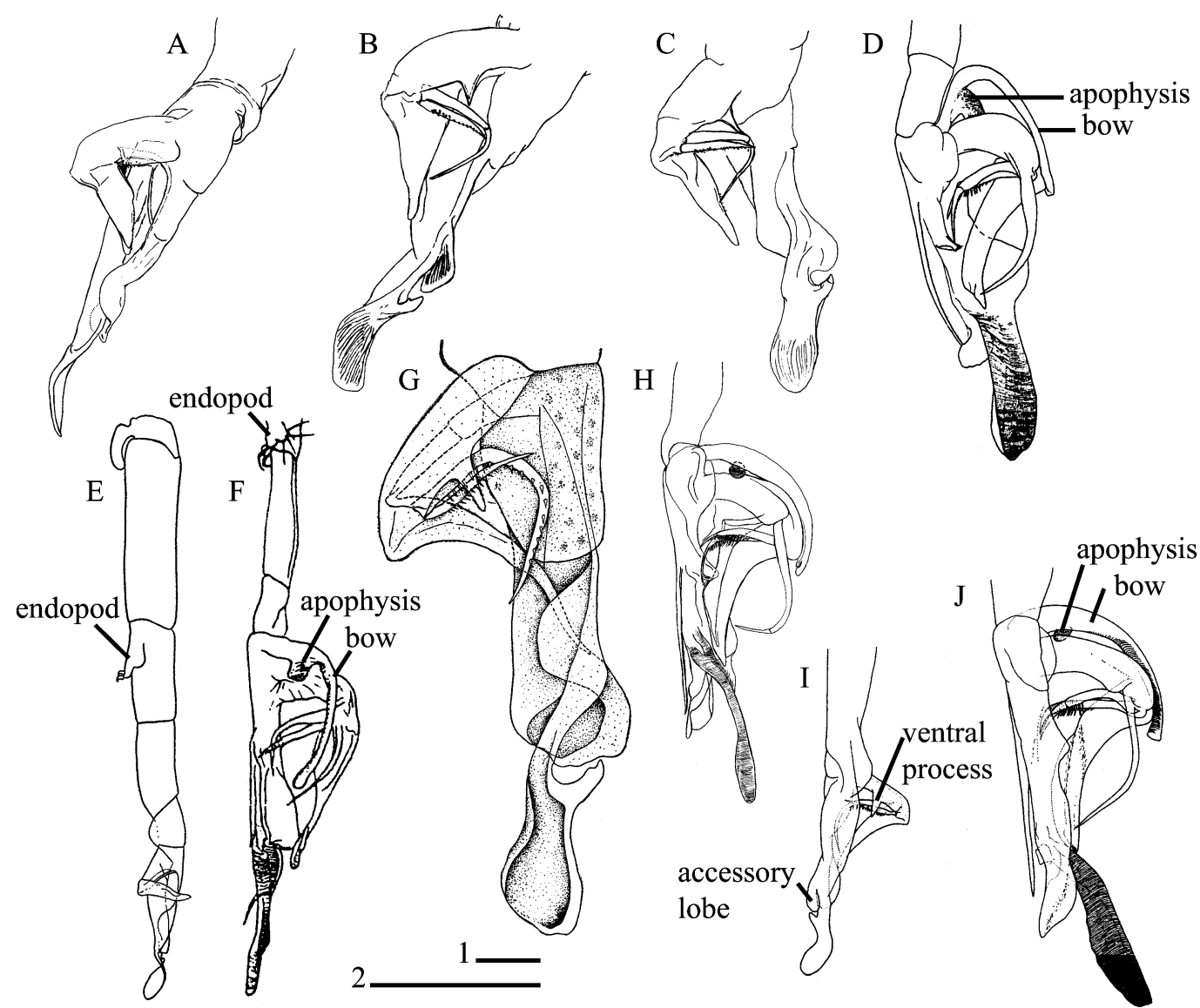

FIGURE 3. Male pleopod 3. Coifmanniella johnsoni (Tattersall, 1937): A-C, penultimate form, various aspects; D, ultimate form (after Brattegard 1970a)._Coifmanniella mexicana (Tattersall, 1951), entire pleopod: E, penultimate form (after Tattersall 1951); F, ultimate form (after Ortiz 1988)._Coifmanniella merjonesi (Băcescu, 1968): G, penultimate form (from Băcescu 1968); H, ultimate form.-Coifmanniella parageia (Brattegard, 1970): I, penultimate (after Brattegard 1970a); J, ultimate form (after Brattegard 1970a). Scale $1=0.1 \mathrm{~mm}$ for A, B, C, G; scale $2=0.5$ mm for D, H, I, J (Scales for E \& F, unavailable).

Remarks. Based on Tattersall's specimens and illustrations, Băcescu (1968) proposed a new name, Bowmaniella banneri for 'Archaeomysis maculata' sensu Tattersall [1932, 1951; not Archaeomysis (=Callomysis) maculata (Holmes, 1894)] from the eastern Pacific waters of southern California (La Jolla), but failed to designate a type. Holmquist (1975) designated a neotype, based on material from Baja California, apparently unaware that Tattersall's (1932) material was deposited in NHM. Later Holmquist (1982) acknowledged that her neotype designation had no standing and that a lectotype should be selected from Tattersall's syntypic material.

Tattersall's (1932) specimens from La Jolla were deposited in the NHM and are considered the syntypes since they represent the series upon which Băcescu (1968) 
designated the specific name Bowmaniella (Coifmanniella) banneri. Dr. Roger Bamber (NHM) kindly located these specimens from Haul 1789 and facilitated the loan of this material to us for study. We have selected and separated a subadult male, which we now formally designate as a lectotype (NHM.1964:1:21:523) for B. banneri (Băcescu, 1968). In addition, the following paralectotypes were chosen: one damaged mature female (NHM.1964:1:21:524) from Haul 1789 and one ovigerous female (NHM.1964:1:21:525) from Haul 432. An illustration of the third pleopod of the penultimate male form (Fig. 6C) is included since it has not been described and is generally similar to that of $B$. dissimilis.

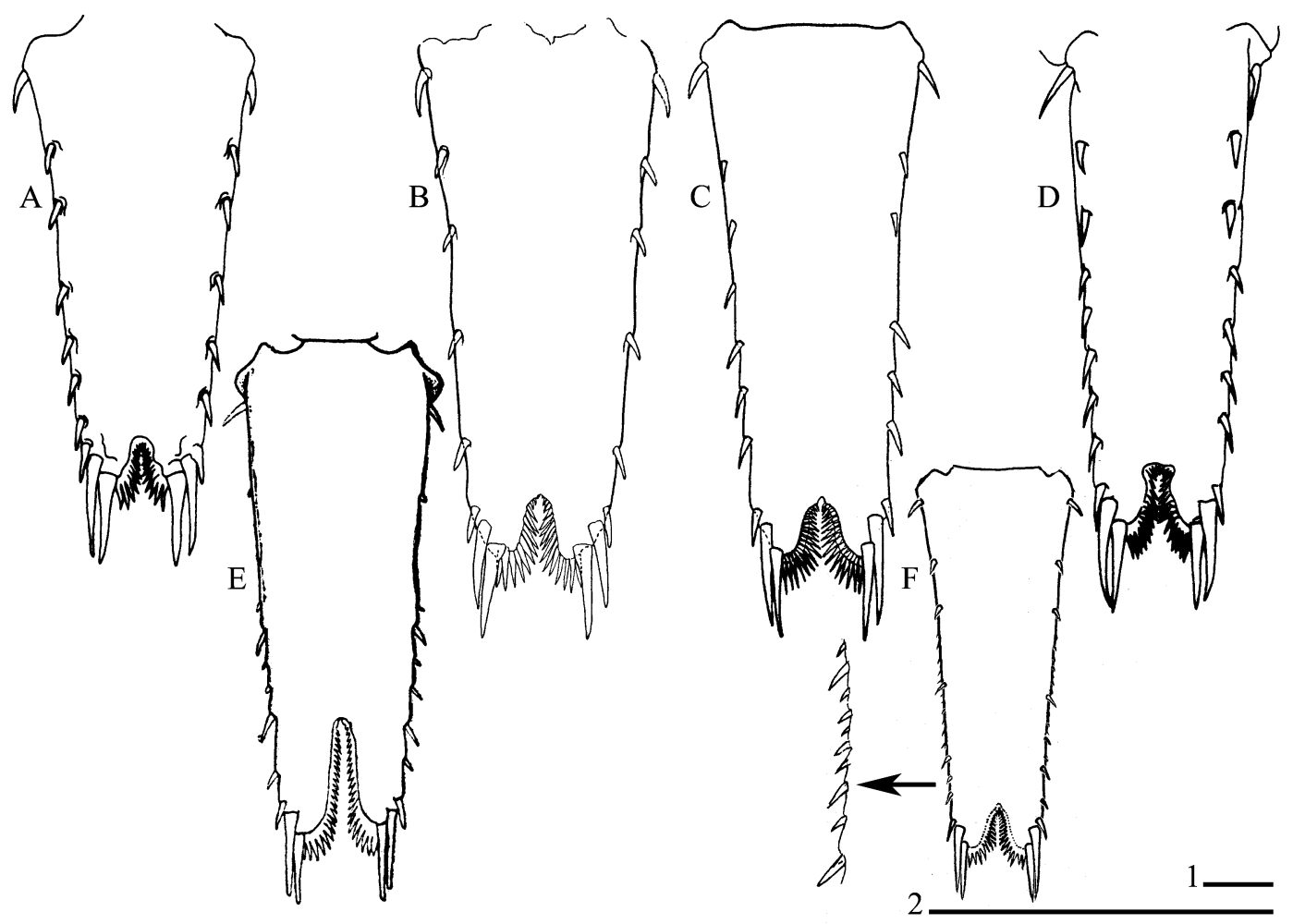

FIGURE 4. Telsons. A, Bowmaniella dissimilis (Coifmann, 1937) (after Stuck et al. 1979a); B. Bowmaniella banneri Băcescu, 1968 (after Holmquist 1975); C, Coifmanniella johnsoni (Tattersall, 1937) (after Tattersall 1937); D, Coifmanniella mexicana (Tattersall, 1951) (after Stuck et al. 1979a); E, Coifmanniella merjonesi (Băcescu, 1968) (after Băcescu, 1968); F, Coifmanniella parageia( Brattegard, 1970) (after Brattegard 1970a) with enlargement of lateral margin showing setation. Scale $1=0.2 \mathrm{~mm}$ for B; scale $2=0.8 \mathrm{~mm}$ for A, C-E; $1.0 \mathrm{~mm}$ for F.

\section{Genus Coifmanniella, n. g.}

Bowmaniella (Bowmaniella) Băcescu, 1968: 356 (in part) (nomen nudum). Bowmaniella (Coifmaniella) Băcescu, 1968: 356 (in part) (nomen nudum). 
Diagnosis. Carapace with posterodorsal margin having mid-dorsal lobe concave posteriorly and adjacent medial lobes attenuated, reflected anterodorsally (Fig. 8G) or non-reflected (Fig. 8F). Male third pleopod complex; terminal male having bow with an associated apophysis, penultimate male having ventral process on outer branch, lacking inner stylet on inner branch (Fig. 2A, B). Abdominal segment 5 with posterodorsal margin lacking articulated process. Uropodal endopod with series of small spiniform setae distal to statocyst. Telson cleft variable, depth from 10 to more than $40 \%$ of total telson length.

Type species. Gastrosaccus johnsoni Tattersall, 1937, here designated.

Other species. C. merjonesi Băcescu, 1968; C. mexicana Tattersall, 1951; C. parageia Brattegard, 1970.

Etymology. The genus is named in honour of Isabella Coifmann, in recognition of her pioneering contribution to the knowledge of Brazilian Mysida.

Remarks. Coifmanniella $\mathbf{n}$. g. is immediately distinguished from the genus Bowmaniella n. g. by lacking an articulated process on the posterodorsal margin of the fifth abdominal segment. Coifmannella further differs from Bowmaniella by: (1) having a bow with an associated apophysis on the terminal male third pleopod; (2) the penultimate male having a ventral process on outer branch and lacking an inner stylet on inner branch; and (3) the presence of small spiniform-setae distal to the uropodal statocyst.

Inconsistencies and confusion in some the characters used by Băcescu (1968) to distinguish the nominal subgenera of Bowmaniella and Coifmanniella led Brattegard (1970a) and Holmquist (1982) to not recognize their validity. Based on the recognition of the distinct differences in the penultimate and ultimate male stages (e.g. development and complexity of the third male pleopod), and in the setation patterns of the uropodal endopod, we have a better understanding of the taxonomy and systematics of Coifmanniella n. g. as diagnosed in this report. This information leads us to synonymise seven of 11 nominal species now attributable to Coifmanniella. The following four species are now recognized.

Coifmanniella johnsoni (Tattersall, 1937)

(Figs. 2A, B, 3A-D, 4C, 5C)

Gastrosaccus johnsoni Tattersall, 1937: 9, figs. 5-7, 1951: 93, figs. 26-28.

Bowmaniella (Bowmaniella) johnsoni.- Băcescu, 1968: 356 (key), figs. 2f, 3c; Brattegard, 1975: 109; Price et al., 2002: 41, fig. 4F; Price \& Heard, 2004: 150, fig. 3E.

Bowmaniella bacescui Brattegard, 1970a: 9 (Tables 7, 8), 20, fig. 5, 1974b: 91; 1975: 109; Modlin, 1984: 281 (new synonymy). 

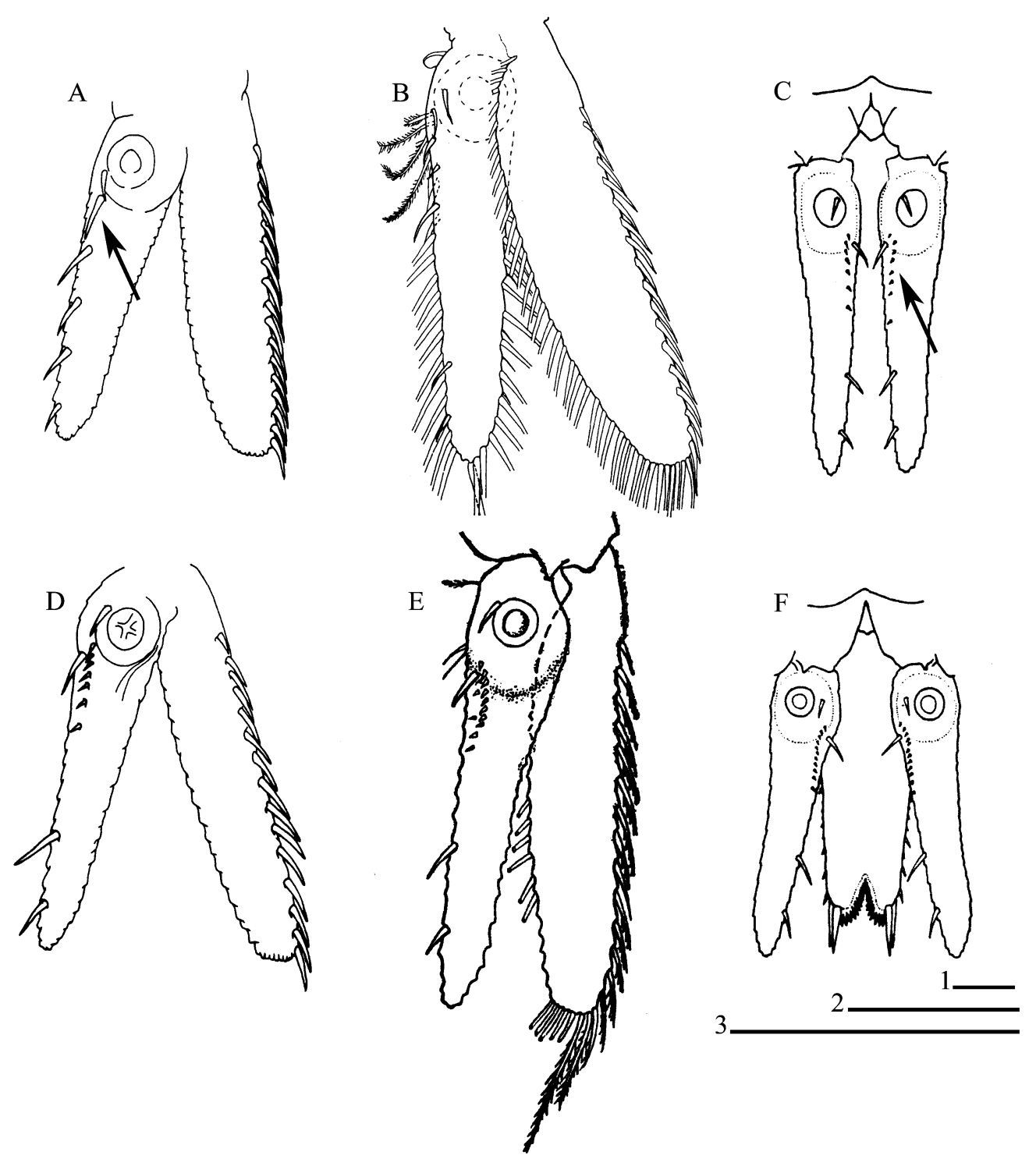

FIGURE 5. Uropods. A, Bowmaniella dissimilis (Coifmann, 1937) (after Stuck et al. 1979a); B. Bowmaniella banneri (Băcescu, 1968) (after Holmquist 1975); C, Coifmanniella johnsoni (Tattersall, 1937) (after Brattegard 1970a); D, Coifmanniella mexicana (Tattersall, 1951) (after Stuck et al. 1979a); E, Coifmanniella merjonesi (Băcescu, 1968) (after Băcescu 1968); F, Coifmanniella parageia (Brattegard, 1970) (after Brattegard 1970a). Scale $1=0.2 \mathrm{~mm}$ for B; scale $2=0.4 \mathrm{~mm}$ for $\mathrm{E}$; $0.7 \mathrm{~mm}$ for $\mathrm{A}, \mathrm{D}$; scale $3=1.0 \mathrm{~mm}$ for $\mathrm{C}, \mathrm{F}$.

\section{Material examined}

Type material: Neotype, $1 \sigma^{\star}$, (here designated), USNM 1019270, east of Puerto Rico, 18 32'18"N, 6546'12"W, Johnson-Smithsonian Expedition, serial no. 358A, 23 Feb 1933.

Other material: $60^{x}, 5$ 우, USNM 82847, east of Puerto Rico, $18^{\circ} 32^{\prime} 18^{\prime \prime} \mathrm{N}$, 65 46'12"W, Johnson-Smithsonian Expedition, serial no. 358A, 23 Feb 1933.—3 o o $^{\circ} 14$ 우 
USNM 81109, Luis Pena channel, Puerto Rico, Johnson-Smithsonian Expedition serial no. 407B, 25 Feb 1933, surface.—2 ox, 4 ㅇ, USNM 8110, Brewers Bay, St. Thomas, Virgin Islands, Johnson-Smithsonian Expedition, 1 Mar 1933, surface.-10 o 5 우, USNM 86030, Icocos Bay, Puerto Rico, Johnson-Smithsonian Expedition, sta 387B, 24 Feb 1933, circular net at anchorage.-2 ox, AMNH 13613 (paratypes of Bowmaniella bacescui), off Port Nelson, Rum Cay, Bahamas, 22 Mar 1968, coll. T. Brattegard, sand and Thalassia substratum, depth 3-5 m.-75 $\circ^{x}, 52$ ㅇ, UT, South Hole Sound, Little Cayman Island, 19 May 1995, coll. W.W. Price, R. W. Heard, J.T. Harris and C.M.R. McCoy, night plankton, 1-2 m.—8 ox, 3 ㅇ, UT, Rum Point, Grand Cayman Island, 1 Sept 1996, coll. R.W. Heard, sand.-10 ox, 7 우, UT, North beach, Pine Cay, Turks and Caicos Islands, 30 Nov 1988, coll. R. Heard, sand depth 1-1.5 m.

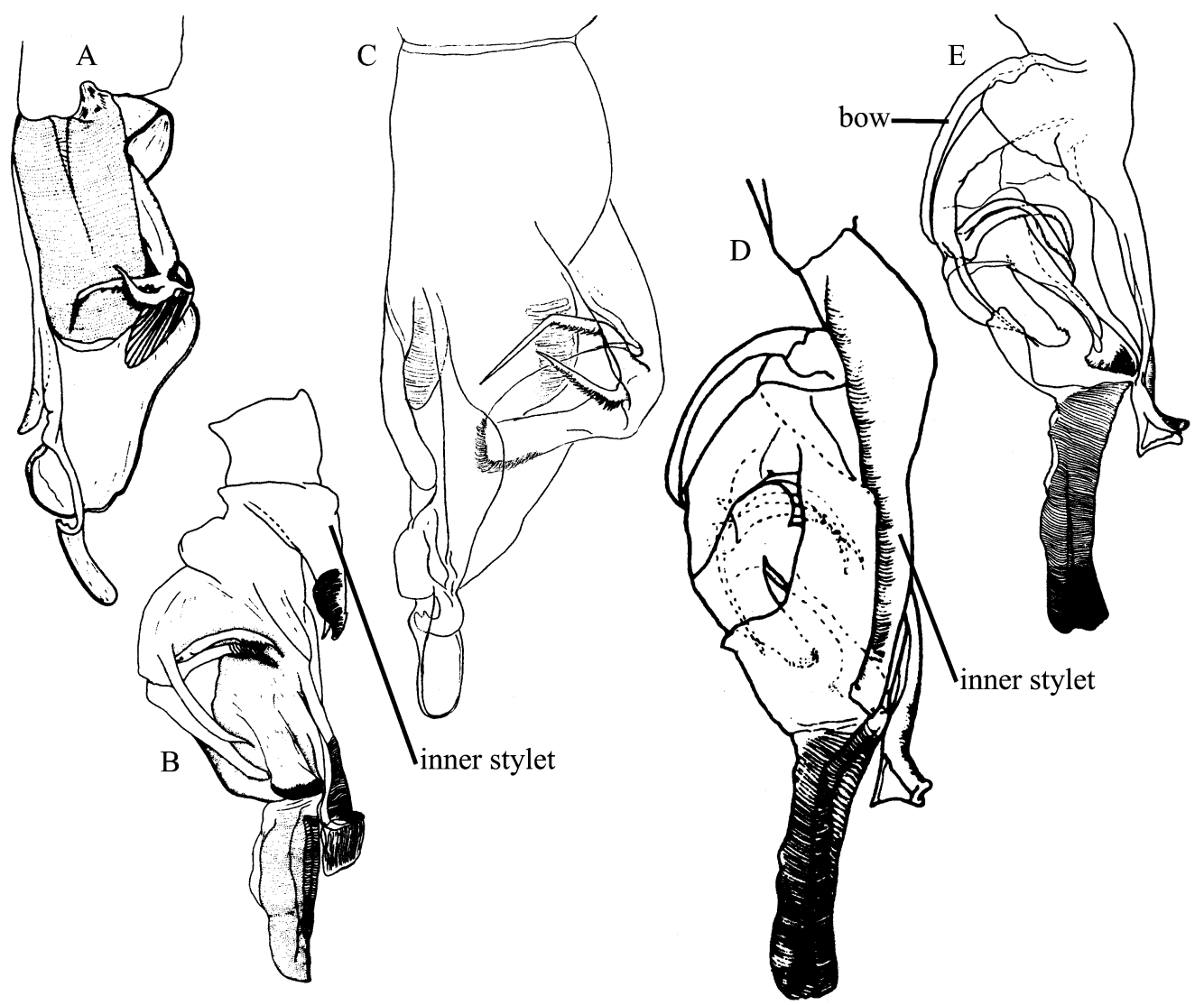

FIGURE 6. Tip of male pleopod 3. Bowmaniella dissimilis (Coifmann, 1937): A, penultimate form (from Stuck et al. 1979a); B, ultimate form (from Stuck et al. 1979a).-Bowmaniella banneri (Băcescu, 1968): C, penultimate form; D, E, ultimate form, lateral and medial aspects, respectively (from Holmquist 1975). Scale $=0.2 \mathrm{~mm}$.

Diagnosis. Posterodorsal margin of carapace not reflected anterodorsally (as in Fig. 8 F). Abdominal somite 5 lacking articulated posterodorsal process. Uropodal endopod with 4 large spiniform setae extending from region of statocyst to distal end, row of 5-9 small 
spiniform setae distal to statocyst. Lateral margins of uropodal exopod armed with rows of 13-15 spiniform setae. Telsonic cleft shallow, less than 1/7 length of telson, armed with 28-32 spinules; lateral margins of telson armed with rows of 6-12 subequal spiniform setae (Fig. 4C).

\section{Type locality. Puerto Rico.}

Distribution. Gulf of Mexico (Modlin 1984); Bahamas (Brattegard 1970a); Caribbean Sea (Brattegard 1970a, 1974b, Price \& Heard 2004).

Remarks. The type (USNM 72868) and type lot of Gastrosaccus johnsoni could not be located and is considered lost (Geoff Keel, personal communication 2004). We examined a large non-type series from the National Museum of Natural History that contained a mixture of Coifmanniella johnsoni and C. merjonesi including both penultimate and ultimate male forms of both species. This material came from near the type locality for $C$. johnsoni and was collected on the same cruise as the original type series (see Tattersall 1937). Because the type series has been lost and the material we examined was collected on the same expedition near the type locality, we have chosen and separated out an ultimate male specimen as a neotype (USNM 1019270) for C . johnsoni. The neotype, which is diagnosed above, came from a non-type lot (USNM 82847), which contained a mixture of $C$. johnsoni and $C$. merjonesi. In our view this further necessitated the selection and separation of a neotype for $C$. johnsoni. .

Examination of male paratypes of Bowmaniella bacescui revealed that they represent the ultimate form of Coifmanniella. johnsoni. Since the third pleopod of the penultimate male form, which is very similar to that of $C$. parageia $(=C$. sewelli), has not been described, we have included its illustration (Fig. 3 A-C). Of the four species of Coifmanniella, C. johnsoni is the only one having a non-reflected posterodorsal margin of the carapace.

\section{Coifmanniella mexicana (Tattersall, 1951)}

(Figs. 3E, F, 4D, 5D)

Gastrosaccus mexicanus Tattersall, 1951: 98, fig. 30.

Bowmaniella (Coifmanniella) mexicana.- Băcescu, 1968: 356 (key).

Bowmaniella mexicana.- Brattegard, 1970a: 9, Tables 7, 8.

Bowmaniella (Bowmaniella) atlantica Silva, 1971: 159 (=Gastrosaccus brasiliensis sensu Silva, 1970: 35, fig. 1) (new synonymy).

Bowmaniella portoricensis Băcescu, 1968: 357, figs.1, 2a-e, 3a-b; Brattegard, 1970a: 9, Tables 7-8; Wigley \& Burns, 1971: 721-722 (map); Stuck et al., 1979a: 227, figs. 2b, 3b, 4b, 5b; 1979b: 244 (new synonymy).

Bowmaniella gutzui Ortiz, 1988: 4, fig. 1 (new synonymy). 


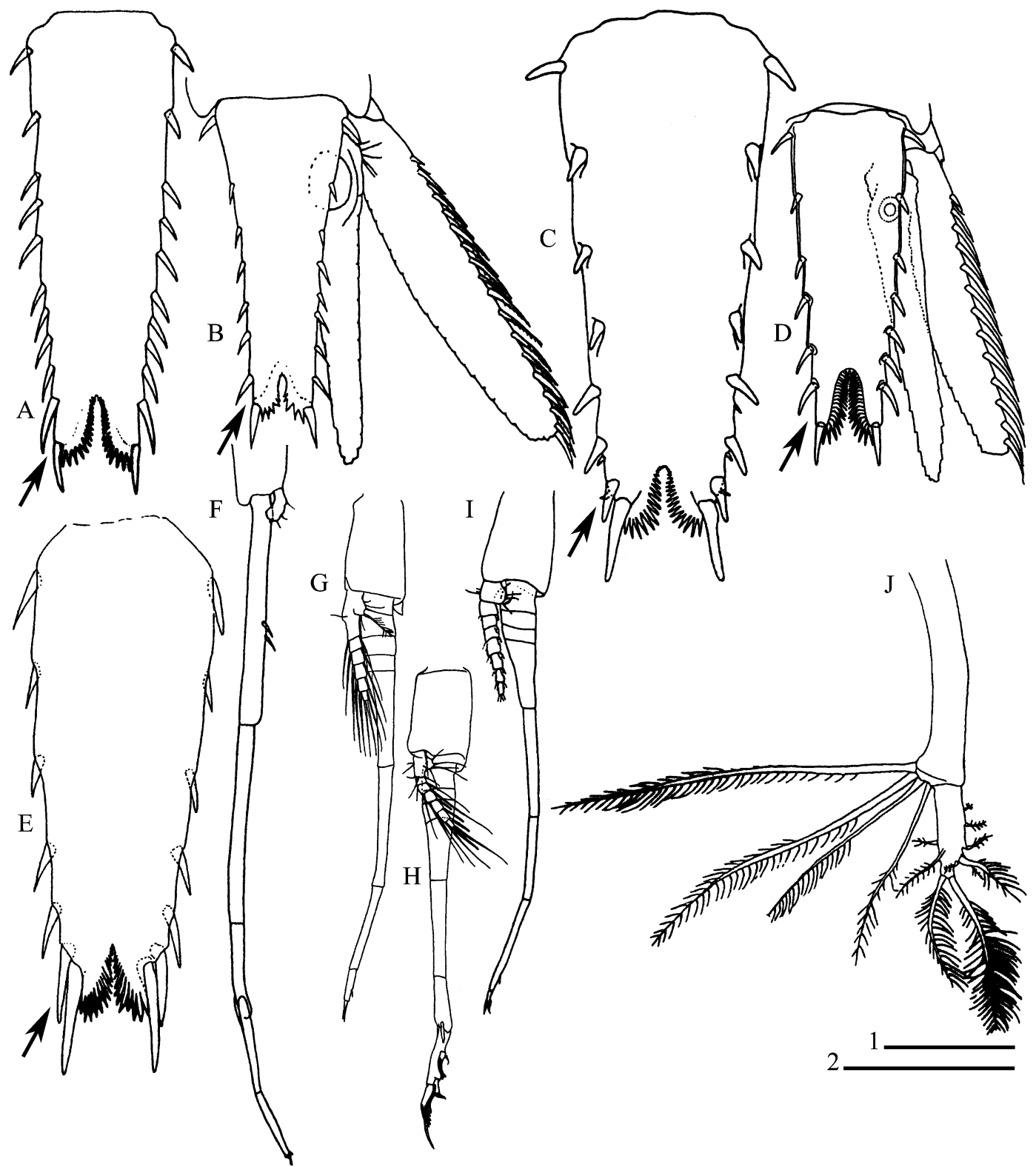

FIGURE 7. Haplostylus similis Panampunnayil, 1997: A, telson (from Panampunnayil 1997).Iiella iriomotensis Fukuoka \& Murano, 1997: B, telson and uropods (from Fukuoka \& Murano 1997)._Gastrosaccus madagascariensis Wooldridge, Mees, \& Webb, 1997: C, telson (from Wooldridge et al. 1997)._Eurobowmaniella simulans (Tattersall, 1915) (= E. phuketensis Murano, 1995) [see Murano, 1996], D, telson and uropods (from Murano 1995).-Archaeomysis kokuboi (Hanamura, 1997): E, telson (from Hanamura 1997).- Hapostylus uthupus Panampunnayil, 1997: F, male pleopod 3.-Gastrosaccus trilobatus Murano \& McLachlan, 1998: G, male pleopod 3.Eurobowmaniella simulans (Tattersall, 1915): H, male pleopod 3 (from Murano 1995)._Iiella iriomotensis Fukuoka \& Murano, 1997: I, male pleopod 3 (from Fukuoka \& Murano 1997)._Iiella iriomotensis Fukuoka \& Murano, 1997: J, female pleopod 1 (from Fukuoka \& Murano 1997). Scale $1=0.2 \mathrm{~mm}$ for $\mathrm{C}, \mathrm{J} ; 0.5 \mathrm{~mm}$ for E-I; scale $2=0.5 \mathrm{~mm}$ for $\mathrm{A}, \mathrm{B}, \mathrm{D}$. 

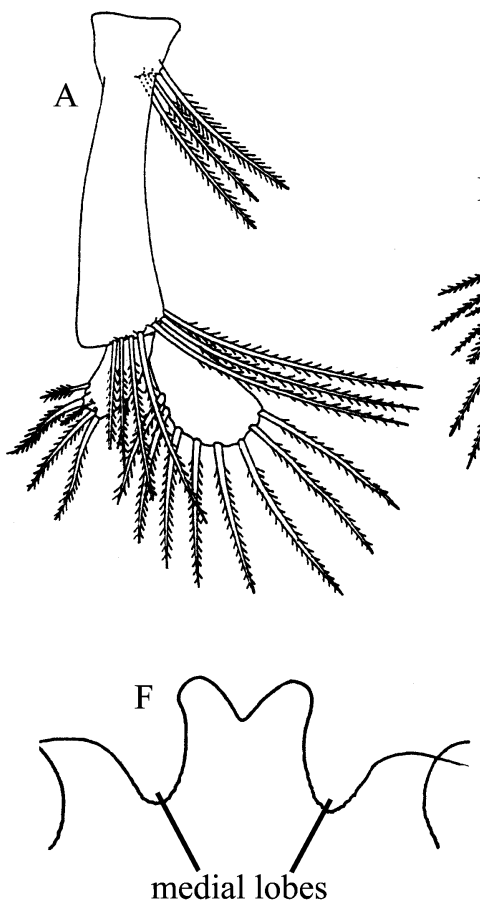
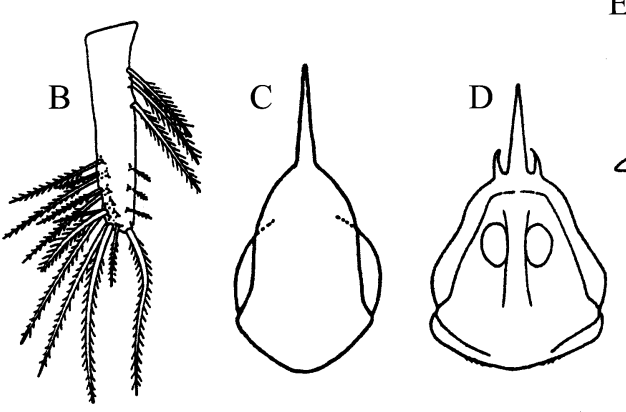

E

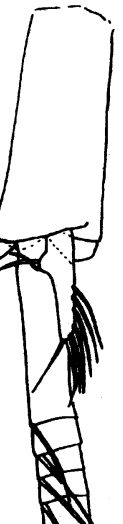

G
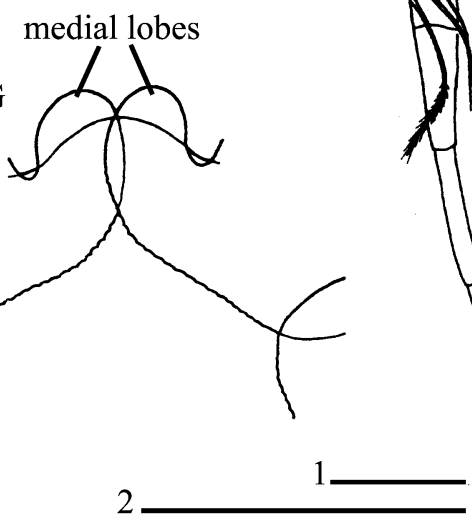

FIGURE 8. Gastrosaccus madagascariensis Wooldridge, Mees, \& Webb, 1997: A, female pleopod 1; B, female pleopod 2 (from Wooldridge et al. 1997)._Gastrosaccus trilobatus Murano \& McLachlan, 1998: C, labrum (from Murano \& McLachlan 1998)._Eurobowmaniella simulans (Tattersall, 1915): D, labrum (from Murano 1995).-Archaeomysis ochotensis Hanamura, 1997: E, male pleopod 3.-Bowmaniella dissimilis (Coifmann, 1937): F, posterior margin of carapace showing non-reflected medial lobes (from Brattegard 1970a).-Coifmanniella parageia (Brattegard, 1970): G, posterior margin of carapace showing reflected medial lobes (from Brattegard 1970a) Scale $1=0.25 \mathrm{~mm}$ for A, B; $0.5 \mathrm{~mm}$ for E; scale $2=0.25 \mathrm{~mm}$ for D; $0.5 \mathrm{~mm}$ for C, F, G.

\section{Material examined}

Type material: Lectotype, ơ, (here designated), USNM 81257, off Cape San Blas, Florida, 7 Mar 1885, surface.-Paralectotypes, 16 immature males, 16 females, USNM 1078333, same data as lectotype.

Other material: 1 व $\sigma^{\star}$ Museum d'Histoire naturelle "Grigore Antipa", Coll. of Crustacea, No. 96 (holotype of Bowmaniella portoricensis), platform off Beaufort, North

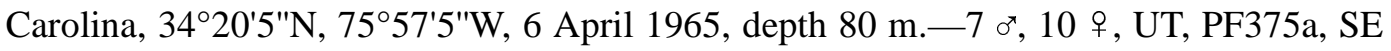
Gulf of Mexico, $26^{\circ} 9^{\prime} \mathrm{N}, 82^{\circ} 12^{\prime} \mathrm{W}, 15$ Nov 1968, coll. R.F. Presley, oblique plankton tow, $9.1 \mathrm{~m}$ to surface. $-6 \circ^{\star}, 7$ ㅇ, UT, PF 592a, NE Gulf of Mexico, $28^{\circ} 50^{\prime} \mathrm{N}, 84^{\circ} 20^{\prime} \mathrm{W}, 8 \mathrm{July}$ 
1969, coll. R.F. Presley, oblique plankton tow, $16.8 \mathrm{~m}$ to surface.-1 $\sigma^{\star}$, USM, BLM 2640E

, NE Gulf of Mexico, $29^{\circ} 43.5^{\prime} \mathrm{N}, 8^{\circ} 54.5^{\prime} \mathrm{W}$, July 1976, box core.-2 $0^{\star}, 2$ ㅇ, USM, BLM

2103C, SE Gulf of Mexico, $26^{\circ} 25^{\prime} \mathrm{N}, 8^{\circ} 58^{\prime} \mathrm{W}$, July 1976, box core. Eastern Pacific: $2{ }^{\star}$, 1 ㅇ, NHM, 1964.1.21.1352, San Jose Island, Gulf of Panama, Panama, 27 Jan 1916, coll. T. Mortensen.

Diagnosis. Posterodorsal margin of carapace reflected anterodorsally (as in Fig. 8 G). Abdominal somite 5 lacking articulated posterodorsal process. Uropodal endopod with 5-8 small spiniform setae distal to statocyst (Fig. 5 D). Telson with lateral margins armed with rows of 4-12 subequal spiniform setae; telsonic cleft shallow, less than 1/5 length of telson (Fig. 4D).

Type locality. Cape San Blas, Gulf of Mexico, Florida.

Distribution. Off southeastern Atlantic coast-90 km north of Cape Hatteras, North Carolina to Fort Pierce, Florida (Wigley \& Burns 1971; Băcescu 1968); eastern Gulf of Mexico (Tattersall 1951; Stuck et al. 1979 b); Cuba (Ortiz 1988); Baia de Sepetiba, Brazil (Silva 1971a); Pacific coast of Panama (Tattersall 1951).

Remarks. Tattersall reported a type lot (USNM 81257) of Gastrosaccus mexicanus composed of 'numerous specimens, mostly immature, but one adult male.' From the syntypes in this type lot, we have separated and here designate the mature male as the lectotype (which retains the original catalogue number, USNM 81257, under which it was published) for Coifmanniella mexicana. Tattersall (1951) reported C. mexicana from the Pacific coast of Panama. We were able to borrow this material from The Natural History Museum, but like Tattersall, were unable to clearly separate it from that of $C$. mexicana from the Gulf of Mexico and Caribbean. There are no other published records of Coifmanniella, as defined here, from the eastern Pacific.

Based on a review of the description and illustrations of Bowmaniella atlantica Silva, 1971 and Bowmaniella gutzui Ortiz, 1988 and the examination of the holotype of $B$. portoricensis Bacescu, 1968, we consider these three nominal species as junior synonyms of Coifmanniella mexicana.

Coifmanniella merjonesi (Băcescu, 1968)

(Figs. 3 G, H, 4E, 5E)

Bowmaniella (Coifmanniella) merjonesi Băcescu, 1968: 356, figs. 7-9; Brattegard, 1970a: 9, tables $7-8$.

Bowmaniella recifensis Silva, 1971: 185, figs. 1, 2 (new synonymy).

Bowmaniella inarticulata Silva, 1972: 161, fig. 1 (new synonymy).

REVISION OF BOWMANIELLA

(C) 2006 Magnolia Press 
Type material: Lectotype ơ (here designated), USNM 86030, Icocos Bay, Puerto Rico, Johnson-Smithsonian Expedition, Sta 387B, 24 Feb 1933, circular net at anchorage.Paralectotypes, $410^{x}, 65$ ․, USNM 1014086, same data as lectotype.

Other material: 1 ox, 1 ㅇ, USNM 81110, Brewers Bay, St. Thomas, Virgin Islands, Johnson-Smithsonian Expedition, 1 Mar 1933, surface.

Diagnosis. Posterodorsal margin of carapace reflected anterodorsally (as in Fig. $8 \mathrm{G}$ ). Abdominal somite 5 lacking articulated posterodorsal process. Uropodal endopod with 6-12 small spiniform setae distal to statocyst (Fig. 5E). Telson with lateral margins armed with rows of 9-16 subequal spiniform setae; telsonic cleft deep, approximately $1 / 3$ or more length of telson (Fig. 4E).

Type locality. Icocos Bay, Puerto Rico.

Distribution. Puerto Rico (Băcescu 1968); Virgin Islands (present study); north Brazil (Silva 1971b, 1972).

Remarks. The deep telsonic cleft, which is a third or more the length of telson, distinguishes this species. Based on the descriptions and illustrations for the Brazilian species, Bowmaniella inarticulata Silva, 1972 and B. recifensis Silva, 1971b, these two species are consider to represent the penultimate and ultimate forms of Coifmanniella merjonesi. Pending study of the types of B. inarticulata and B. recifensis, which were unavailable for examination, we consider them as junior subjective synonyms of $C$. merjonesi.

When naming Bowmaniella merjonesi, Băcescu (1968) failed to designate a holotype; however, his description and illustration are for a penultimate male. From the 42 subadult, penultimate, and ultimate males available in the type series, we selected a penultimate male as the lectotype (USNM 86030) for Coifmanniella merjonesi because it represents the form described and illustrated in Băcescu's (1968) original description. For comparison the third pleopod for the ultimate male form is illustrated (Fig. $3 \mathrm{H}$ ) since it was not figured or described by Băcescu (1968).

\section{Coifmanniella parageia (Brattegard, 1970)}

(Figs. 3I-J, 4F, 5F, 8G)

Bowmaniella parageia Brattegard, 1970a: 17, fig. 4, tables 7-8.

Bowmaniella sewelli Brattegard, 1970a: 14, fig. 3, tables 7-8, 1970b: 122, 1974a: 51, 1974b: 92, 1975: 110; Modlin, 1984: 280 (new synonymy). 
Material examined. 40 o $\sigma^{*}$ AMNH 13609 (paratypes-Bowmaniella sewelli), Turtle (paratypes-Bowmaniella parageia), Turtle Rocks, Bahamas, 9 May 1967, coll. T. Brattegard, night plankton.

Diagnosis. Posterodorsal margin of carapace reflected anterodorsally (Fig. 8 G). Abdominal somite 5 lacking articulated posterodorsal process. Uropodal endopod with 7-16 small spiniform setae distal to statocyst (Fig. 5F). Telson with lateral margins armed with rows of 12-25 spiniform setae, 6-8 larger interrupted by smaller ones; telsonic cleft shallow, less than $1 / 5$ length of telson (Fig. 4F).

Type locality. Near Long Island, Bahamas (22 $\left.55^{\prime} 10^{\prime \prime} \mathrm{N}, 74^{\circ} 54^{\prime} 35^{\prime \prime} \mathrm{W}\right)$.

Distribution. Gulf of Mexico (Modlin 1984), Bahamas, Florida Keys, southern and western Caribbean (Brattegard 1970 a, b; 1974 a, b).

Remarks. Coifmanniella parageia (Brattegard, 1970), which is the terminal form of $C$. sewelli Brattegard, 1970, is designated as the senior synonym since it represents the ultimate male stage for the species. It is interesting to note that most of the paratypes chosen by Brattegard (Brattegard, 1970) for both male forms of C. parageia and C. sewelli were taken from the same sample in the Bahamas.

\section{Discussion}

The burrowing genera Archaeomysis Czerniavsky, 1882, Bowmaniella Băcescu, 1968, Coifmanniella Băcescu, 1968, Gastrosaccus Norman, 1868, Haplostylus Kossman, 1880, Iiella Băcescu, 1968, and Eurobowmaniella Murano, 1995 are distinguished by having a greatly elongated exopod on the pleopod 3 of the male and the expansion of the pleura of the first abdominal segment on the female (Hanamura 1997), the latter character being an apparent adaptation to support and protect the marsupium during burrowing. The following key can be used to distinguish these seven burrowing genera.

Three genera, Anchialina Norman \& Scott, 1906, Pseudanchialina Hansen, 1910 and Paraanchialina Hansen, 1910, which are currently assigned to the subfamily Gastrosaccinae, are primarily planktonic and not specifically adapted for burrowing. The males of these three species have relatively short third pleopods bearing numerous natatory plumose setae and the females lack the expanded pleura on the first abdominal segment. Using morphological evidence, Hanamura (1997) pointed out that the burrowing and non-burrowing genera represent two separate lineages. Remerie et al. (2004) corroborated these findings using molecular data and suggested that consideration be given to dividing the Gastrosaccinae into two subfamilies. 
Based on recognition of two distinct forms of the male third pleopod for members of both Bowmaniella and Coifmanniella, developmental studies on the males of the other burrowing members of the Gastrosaccinae would be in order. Such studies would be especially applicable in habitats where males of two nominal congeneric species have been reported to co-occur. It would be useful to determine (based on examination of the third pleopod) whether or not the males of two distinct species are present, or if the two male forms represent developmental stages of the same species.

\section{Key to the burrowing genera of the subfamily Gastrosaccinae and to the currently recognized species of Bowmaniella, n. g. and Coifmanniella, n. g.}

1. Pairs of strong terminal spiniform-setae of telson usually not inserted closely to subterminal setae on either side; if close together, subterminal setae less than $2 / 3$ length of terminal setae (Fig. 7A-E)

- Pairs of strong terminal and subterminal spiniform-setae of telson subequal (subterminal setae $2 / 3$ or more length of terminal setae and inserted close together on either side (Fig. 4)

2. Endopod of male pleopod 3 small, uniarticulated (Fig. 7 F)

Haplostylus Kossmann, 1880

- Endopod of male pleopod 3 multiarticulated (Fig. 7 G-I)

3. All pleopods of female uniramous (Fig. $7 \mathrm{~J}$ ) Iiella Băcescu, 1968

- Pleopod 1 of female biramous (Fig 8 A); pleopods 2-5 uniramous (Fig. 8B) ............ 4

4. Male pleopod 3 with simple styliform exopod (Fig. $7 \mathrm{G}$ ); anterior margin of labrum with long median spine (Fig. 8 C). Gastrosaccus Norman, 1868

- Male pleopod 3 with complex exopod (Fig. $7 \mathrm{H}$ ); anterior margin of labrum with long median spine and pair of shorter lateral spines (Fig. $8 \mathrm{D}$ )

Eurobowmaniella Murano, 1995

5. Male pleopod 3 simple, styliform; endopod uniarticulated or multiarticulated (Fig. 8 E) Archaeomysis Czerniavsky, 1882

- Male pleopod 3 complex, not styliform, endopod uniarticulated (Figs. 1, 2, 3, 6) ..... 6

6. Abdominal somite 5 with articulated posterodorsal process (Fig. 1); no small-spiniform setae distal to statocyst on uropodal endopod (Fig. 5A, B)

Bowmaniella, n. $\mathbf{g}$

- Abdominal somite 5 without articulated postero-dorsal process; 2-16 small spiniformsetae distal to statocyst on uropodal endopod (Fig. 5C-F) Coifmanniella, n. g. 8

7. Exopod of male pleopod 3 of ultimate form with bow, inner branch with inner stylet fairly slender, reaching more than one-half length of distal article (Fig. 6D, E) )

B. banneri (Băcescu, 1968)

- Exopod of male pleopod 3 of ultimate form lacking bow, inner branch with inner stylet short and robust, reaching less than one-half length of distal article (Fig. 2 D; 
Fig. 6 B)

8. Telsonic cleft deep, approximately $1 / 3$ or more length of telson (Fig. 4E); [posterodorsal margin of carapace reflected anterodorsally as in Fig. 8G]

C. merjonesi (Băcescu, 1968)

Telsonic cleft shallow, less than 1/5 length of telson (Fig. 4C, D, F)

9. Posterodorsal margin of carapace not reflected anterodorsally (as in Fig. 8 F)

C. johnsoni (Tattersall, 1937)

- Posterodorsal margin of carapace reflected anterodorsally (Fig. $8 \mathrm{G}$ )

10. Lateral margins of telson armed with rows of 4-12 subequal spiniform setae (Fig. 4 D)

C. mexicana (Tattersall, 1951)

- Lateral margins of telson armed with rows of 16-22 spiniform setae, 6-8 larger interrupted by smaller ones (Fig. 4F) C. parageia (Brattegard, 1970)

\section{Acknowledgments}

We wish to thank Jana Thoma, Brent Thoma, and Micah Bakenhaster for their help in preparing the figures and Sara LeCroy, Jerry McLelland, David Knott, and Robin Overstreet for their constructive comments on the manuscript. During the preparation of this paper, several people have assisted with the loan of specimens and selection of type material. They include Jan Clarke-Walker, Geoff Keel, Karen Reed, Chad Walter (National Museum of Natural History); J. Cordeiro (American Museum of Natural History); Iorgu Petrescu (Muséum d'Histoire naturelle "Grigore Antipa"); Roger Bamber (The Natural History Museum, Great Britain); Gianna Innocenti (Museo Zoologico de "La Specola"), and Cristiana Serejo (Museu Nacional, Rio de Janeiro, Brazil). We are indebted to the following journals and publishers for permission to use illustrations for which they hold the copyright: Gulf and Caribbean Research (citation: Stuck et al. 1979a); Journal of Crustacean Biology (citation: Fukuoka and Murano 1997); Travaux du Muséum d'Histoire naturelle "Grigore Antipa" (citation: Băcescu 1968); Oxford University Press, representing Journal of Plankton Research (citation: Panampunnayil 1997); Phuket Marine Biological Centre Research Bulletin (citation: Murano 1995); Springer Science and Business Media, Kluwer Academic Publishers, representing Hydrobiologia (citation: Wooldridge et al. 1997); Taylor and Francis AS, representing Sarsia (www.tandf.no/ sarsia) (citation: Brattegard 1970a); Taylor and Francis Ltd, representing Journal of Natural History (http://www.tandf.co.uk/journals) (citation: Hanamura 1997). We also thank the following authors for use of illustrations from their publications: Y. Hanamura, C. Holmquist, M. Ortiz, S. Panampunnayil and T. Wooldridge. We very much appreciate the thoughtful and constructive suggestions of associate editor Niel Bruce, and of the two anonymous reviewers, and take full responsibility for any of the suggested changes that we chose not to address. 
Almeida Prado, M.S. de (1973) Distribution of Mysidacea (Crustacea) in the Cananeia region. Boletim Zoologico e Biologica Marina, 30, 395-417.

Băcescu, M. (1968) Contributions to the knowledge of the Gastrosaccinae psammobionte of the Tropical America, with the description of a new genus (Bowmaniella, n. g.) and three new species of its frame. Travaux du Muséum d'Histoire naturelle "Grigore Antipa", 8, 355-373.

Banner, A.H. (1948) A taxonomic study of the Mysidacea and Euphausiacea (Crustacea) of the northeastern Pacific. Part I. Mysidacea, from family Lophogastrida through tribe Erythropini. Transactions of the Royal Canadian Institute, 26, 345-399.

Brattegard, T. (1970a) Mysidacea from shallow water in the Bahamas and southern Florida. Part 2. Marine Biological Investigations in the Bahamas. Sarsia, 41, 1-35.

Brattegard, T. (1970b) Mysidacea from shallow water in the Caribbean Sea. Sarsia, 43,111-154.

Brattegard, T. (1974a) Additional Mysidacea from shallow water on the Caribbean coast of Colombia. Sarsia, 57, 47-86.

Brattegard, T. (1974b) Mysidacea from shallow water on the Caribbean coast of Panama. Sarsia, $57,87-108$.

Brattegard, T. (1975) Shallow-water Mysidacea from the Lesser Antilles and other Caribbean regions. Studies on the Fauna of Curacao and Other Caribbean Islands, 157, 102-115.

Christmas, J.Y. \& Langley, W. (1973) Estuarine invertebrates, Mississippi. In: Christmas, J. Y. (Ed.) Gulf of Mexico Estuarine Inventory and Study, Mississippi, Gulf Coast Research Laboratory, Ocean Springs, Mississippi, 255-319.

Coifmann, I. (1937) Misidacei raccolti dalla R. Corvetta Vettor Pisani negli anni 1882-85. Annuario del Museo Zoollogico della R. Università Napoli, N. S., 7, 1-14.

Conte, F. \& Parker, J. (1972) Ecological aspects of selected Crustacea of two marsh embayments of the Texas coast. Texas A \& M University Sea Grant Program, 184 pp.

Cooley, N.R. (1978) An inventory of the estuarine fauna in the vicinity of Pensacola, Florida. Florida Marine Research Publication, 31, 1-119.

Costa, H.R. da. (1964) Notas sôbre os Mysidacea da Costa Brasileira. Boletim do Museu Nacional, Rio de Janeiro (Zoologia.), Nova serie, 247, 1-9.

Czerniavsky, V. (1882) Monographia Mysidarum inprimis Imperii Rossici. Fasc. 1.Trudy SanktPetersburgstva obschestwo Estesvoitpytatelei, 12, 1-170.

Dexter, D.M. (1974) Sandy-beach fauna of the Pacific and Atlantic coasts of Costa Rica and Colombia. Revista de Biologia Tropical, 22, 51-66.

Escobar-Briones, E. \& Soto, L.A. (1988) Mysidacea from Términos Lagoon, southern Gulf of Mexico and description of a new species of Taphromysis. Journal of Crustacean Biology, 8, 639-655.

Fukuoka, K. \& Murano, M. (1997) Mysidacea from coastal waters of Iriomote Island, Ryukyu Islands, southwestern Japan, with descriptions of three new species. Journal of Crustacean Biology, 17, 520-537.

Hanamura, Y. (1997) Review of the taxonomy and biogeography of shallow-water mysids of the genus Archaeomysis (Crustacea: Mysidacea) in the North Pacific Ocean. Journal of Natural History, 31, 669-711.

Hansen, H.J. (1910) The Schizopoda of the Siboga Expedition. Siboga Expeditie, 37, 1-123.

Haworth, A.H. (1825) A new binary arrangement of the macrurous Crustacea. Philosophical Magazine and Journal of Natural Philosophy, Chemistry and Arts, 65, 183-184.

Heard, R.W. (1982) Guide to common tidal marsh invertebrates of the northeastern Gulf of Mexico, MASGP-79-004, Mississippi Alabama Sea Grant Consortium 82 pp.

Holmes, S.J. (1894) Notes on west American Crustacea. Proceedings of the California Academy of Sciences, 6, 563-588. 
Holmquist, C. (1975) A revision of the species Archaeomysis grebnitzkii Czerniavsky and A. maculata (Holmes) (Crustacea, Mysidacea). Zoologische Jahrbücher Abteilung für Systematik Okologie und Geographie der Tiere, 102, 51-71.

Holmquist, C. (1982) Mysidacea (Crustacea) secured during investigations along the west coast of North America by the National Museums of Canada, 1955-1966, and some inferences drawn from the results. Zoologische Jahrbücher Abteilung für Systematik Okologie und Geographie der Tiere, 109, 469-510.

Hopkins, T.L. (1965) Mysid shrimp abundance in surface waters of Indian River Inlet, Delaware. Chesapeake Science, 6, 86-91.

Hopkins, T.L. (1966) The plankton of the St. Andrew Bay system. Publications of the Institute of Marine Science, University of Texas, 11,12-64.

Ii, N. (1964) Mysidae (Crustacea) Fauna Japonica. Biogeographical Society of Japan, Tokyo, 610 pp.

International Commission on Zoological Nomenclature (1999). International Code of Zoological Nomenclature. The International Trust for Zoological Nomenclature. Fourth Edition, London, 306 pp.

Jo, S.-G., Ma, C.-W., Suh, H.-P. \& Hong, S.J. (1998) Mysidacea (Crustacea) from the Korea Strait and its adjacent waters. Korean Journal of Biological Sciences, 2, 33-47.

Kossmann, R. (1880) Malacostraca. (2 Theil Anditura), Zoologische Ergebnisse einer Reise in die Kustengebeite des Rothen Meeres, Leipzig, 2, 67-180.

Livingston, R.J., Sheridan, P.F., McLane, C.G., Lewis, III, F.G. \& Kobylinski, G.G. (1977) The biota of the Apalachicola Bay system: Functional relationships. In R. J. Livingston and E. A. Joyce, Jr. (Eds.), Proceedings of the Conference on the Apalachicola Drainage System, 23 April 1976, Florida Marine Research Publication, 26, 75-100.

Modlin, R.F. (1982) Contributions to the ecology of the mysid crustaceans in the shallow waters of Dauphin Island, Alabama. Northeast Gulf Science, 5, 45-49.

Modlin, R.F. (1984) Mysidacea from the Florida Middle Ground, northeast Gulf of Mexico with descriptions of three new species of Heteromysis and a key to the Heteromysini of the western Atlantic. Journal of Crustacean Biology, 4:278-297.

Murano, M. 1996. Note on withdrawal of Eurobowmaniella phuketensis and transferrence of Gastrosaccus simulans Tattersall to its genus (Crustacea: Mysidacea). Phuket Marine Biological Centre Research Bulletin, 61, 65-66

Murano, M. (1995) Eurobowmaniella phuketensis n. gen. n. sp. (Crustacea: Mysidacea) from the Indian coast of Thailand. Phuket Marine Biological Centre Research Bulletin, 60, 21-28.

Norman, A.M. (1868) Preliminary report on the Crustacea, Molluscoida, Echinodermata, and Coelenterata, procured by the Shetland Dredging Committee in 1867. Report of the British Association for the Advancement of Science, 37, 437-441.

Norman, A. M. (1892) On British Mysidae, a family of Crustacea Schizopoda. Annals Magazine of Natural History, 10, 143-166.

Norman, A.M. \& Scott, T. (1906) Mysidacea. In: The Crustacea of Devon and Cornwall, W. Wesley and Son, London, 23-28.

Odum, W.E. \& Heald, E.J. (1972) Trophic analysis of an estuarine mangrove community. Bulletin of Marine Science, 22, 671-738.

Ortiz, M. (1988) Una nueva especie de misdiáceo del género Bowmaniella (Crustacea: Mysidacea), de aguas cubanas. Revista de Investigaciones Marinas, 9, 3-7.

Ortmann, A.E. (1893) Decapoden und Schizopoden. In: Hensen, V. (Ed), Ergebnisse der Plankton, Expedition der Humboldt-Stiftung, Kiel und Leipzig, Lipsius und Tischer, 2,1-120.

Panampunnayil, S.U. (1997) Descriptions of five new species of Haplostylus (Mysidacea-Crustacea) from south west Australia. Journal of Plankton Research, 19, 1205-1233.

Price, W.W. (1978) Occurrence of Mysidopsis almyra Bowman, M. bahia Molenock and Bow- 
maniella brasiliensis Băcescu (Crustacea, Mysidacea) from the eastern coast of Mexico. Gulf Research Reports, 6, 173-175.

Price, W.W. (1982) Key to the shallow water Mysidacea of the Texas coast with notes on their ecology. Hydrobiologia, 93, 9-21.

Price, W.W. \& Heard, R.W. (2004) Studies on the Crustacea of the Turks and Caicos Islands, British West Indies. V. Records of mysids from Pine Cay, Fort George Cay, Water Cay, and adjacent waters. Gulf and Caribbean Research, 16, 147-159.

Price, W.W., Heard, R.W., Harris, J.T. \& McCoy, C.M.R. (2002) Crustacea of the Cayman Islands, British West Indies. I. Records of mysids from shallow water non-reef habitats. Gulf and Caribbean Research, 14, 35-52.

Rakocinski, C.F., Heard, R.W. Simons, T. \& Gladhill, D. (1991) Macroinvertebrate associations from beaches of selected barrier islands in the northern Gulf of Mexico: important environmental relationships. Bulletin of Marine Science, 43, 689-701.

Rakocinski, C.F., Heard, R.W. LeCroy, S.E., McLelland, J.A. \& Simons, T. (1993) Seaward change in zonation of the sandy-shore macrofauna at Perdido Key, Florida, USA. Estuarine, Coastal and Shelf Science, 36, 81-104.

Rakocinski, C.F., Heard, R. W. LeCroy, S. E., McLelland, J. A. \& Simons, T. (1996) Responses by macrobenthic assemblages to extensive beach restoration at Perdido Key, Florida, U S A. Journal of Coastal Research, 12, 326-353.

Remerie, T., Bulckaen, C., Calderon, J., Deprez, T., Mees, J., Vanfleteren, J., Vanreusel, A., Vierstraete, A., Vincx, M., Wittmann, K. J. \& Wooldridge, T. (2004) Phylogenetic relationships within the Mysidae (Crustacea, Peracarida, Mysida) based on nuclear 18S ribosomal RNA sequences. Molecular Phylogenetics and Evolution, 32, 770-777.

Silva, V.M. A.P. Da (1970) Gastrosaccus brasilensis nova espécie de Crustacea Mysidacea. Atas da Sociedade de Biologia do Rio de Janeiro, 13, 35-36.

Silva, V.M.A.P. Da (1971a) Bowmaniella (Bowmaniella) atlantica, novô nome para Gastrosaccus brasilensis (da Silva, 1970) (Crustacea, Mysidacea). Atas da Sociedade de Biologia do Rio de Janeiro, 14, 159.

Silva, V.M. A.P. Da (1971b) Bowmaniella (Bowmaniella) recifensis n. sp. de Crustacea Mysidacea. Atas da Sociedade de Biologia do Rio de Janeiro, 14, 185-187.

Silva, V.M.A.P. Da (1972) Bowmaniella (Coifmanniella) inarticulata sp. n. de Crustacea Mysidacea. Atas da Sociedade de Biologia do Rio de Janeiro, 15, 161-163.

Stuck, K.C., Perry, H.M. \& Heard, R.W. (1979a) An annotated key to the Mysidacea of the North central Gulf of Mexico. Gulf Research Reports, 6, 225-238.

Stuck, K., Perry, H.M. \& Heard, R.W. (1979b) Records and range extensions of Mysidacea from coastal and shelf waters of the eastern Gulf of Mexico. Gulf Research Reports, 6, 239-248.

Takahashi, K. \& Kawaguchi, K. (1997) Diel and tidal migrations of the sand-burrowing mysids, Archaeomysis kukuboi, A. japonica and Iiella ohshimai, in Otscuchi Bay, northeastern Japan. Marine Ecology Progress Series, 148, 95-107.

Tattersall, W.M. (1932) Contributions to a knowledge of the Mysidacea of California, I: On a collection of Mysidae from La Jolla, California. University of California Publications in Zoology, 37, 301-314.

Tattersall, W.M. (1937) New species of mysidacid crustaceans. Smithsonian Miscellaneous Collections $91,1-18$.

Tattersall, W.M. (1951) A review of the Mysidacea of the United States National Museum. Bulletin of the United States National Museum, 201, 1-292.

Wigley, R.L. \& Burns, C.R. (1971) Distribution and biology of mysids (Crustacea, Mysidacea) from the Atlantic coast of the United States in the NMFS Woods Hole collection. Fishery Bulletin, 69, 717-746.

Williams, A.C. (1972) A ten-year study of meroplankton in North Carolina estuaries: mysid 
shrimps. Chesapeake Science, 13, 254-262.

ZOOTAXA

Wooldridge, T., Mees, J. \& Webb, P. (1997) A new species of Gastrosaccus (Crustacea, Mysidacea) from beaches in Madagascar. Hydrobiologia, 354, 119-126. 


\section{ZOOTAXA}

(1269) 